\title{
Efektivitas Model Problem Based Learning dan Make A Match dalam Pembelajaran Tematik Kelas V SD Negeri Sidorejo Lor 04 yang Ditinjau dari Keterampilan Berpikir Kritis
}

\author{
Asuan $^{1 *}{ }^{*}$ Mawardi $^{2}$, Krisma Widi Wardani ${ }^{3}$ \\ ${ }^{123}$ Universitas Kristen Satya Wacana, Jalan Diponegoro 52-60 Salatiga, Jawa Tengah
}

\author{
A R T I C LE IN F O \\ Article history: \\ Received 18 May 2019 \\ Received in revised form \\ 30 June 2019 \\ Accepted 15 July 2019 \\ Available online 25 August \\ 2019 \\ Kata Kunci: \\ Problem Based Learning \\ Make A Match \\ Pembelajaran Tematik, \\ Keterampilan Berpikir Kritis \\ Keywords: \\ Problem Based Learning, \\ Make A Match, Thematic \\ Learning, Critical Thinking \\ Skills
}

\begin{abstract}
A B S T R A K
Penelitian ini bertujuan untuk mengetahui efektivitas penerapan model Problem Based Learning dan Make A Match dalam pembelajaran Tematik siswa kelas 5 SD Negeri Sidorejo lor 04 dan SD Negeri Sidorejo lor 05 ditinjau dari keterampian berpikir kritis. Subyek dalam penelitian ini adalah siswa kelas 5 SD Negeri Sidorejo Lor 04 sebagai kelas eksperimen dan SD Negeri Sidorejo Lor 05 sebagai kelas kontrol. Jenis penelitian ini adalah penelitian quasi experiment jenisPretestPosttest Control Group Design merupakan jenis design yang dipilih. Sampel yang diambil adalah 72 siswa. Hasil penelitian menunjukkan bahwa penggunaan model pembelajaran Problem Based Learning dan Make A Match dapat meningkatkan keterampilan berpikir kritis dalam menyelesaikan soal pada mata pelajaran Tematik di kelas 5 SD Negeri Sidorejo Lor 04 dan SD Negeri Sidorejo Lor 05. Hal tersebut dapat dibuktikan dari meningkatnya keterampilan berpikir kritis siswa dari kelas eksperimen 74,21 (cukup kritis) daan kelas kontrol yaitu 60,82 (tidak kritis). Dari uji Ancova pada muatan Bahasa Indonesia 1,570 taraf signifikansi atau probabilitas 0,214. Oleh karena probabilitas 0,214. Oleh karena probabilitas $0,214>0,05$, maka Ho diterima, dan $\mathrm{Ha}$ ditolak. Sedangkan pada muatan IImu Pengetahuan Alam $F$ hitung 0,334 taraf signifikansi atau probabilitas 0,565 , maka Ho diterima dan
\end{abstract} $\mathrm{Ha}$ ditolak. Artinya model Problem Based Learning lebih efektif secara signifikan dari pada model Make A Match ditinjau dari keterampilan berpikir kritis Tematik pada peserta didik kelas 5 SD Negeri Sidorejo Lor 04 dan SD Negeri Sidorejo Lor 05.

\section{A B S T R A C T}

Problem-Based Learning Model and Matching in Thematic Learning at fifth grade students of SD Negeri Sidorejo lor 04 and SD Negeri Sidorejo lor 05 viewed from the appearance of critical thinking. The subjects in this study were fifth grade students at Sidorejo Lor 04 Elementary School as an experimental class and Sidorejo Lor 05 Elementary School as a control class. This type of research is a quasi-experimental research type Test-Posttest Control Group Design. The Samples are 72 students. The results showed that the use of Problem Based Learning model can enhance learning about critical problems in Thematic subjects in fifth grade stdents at SD Negeri Sidorejo Lor 04 and SD Negeri Sidorejo Lor 05. It can be prove from what is supported by student's critical thinking from the experimental class 74.21 (quite critical) and the control class 60.82 (uncritical). From the Ancova test on the calculation of Indonesian Language 1,570 level of significance or probability is 0.214 . Therefore the probability is 0.214 . Because of the probability $0.214>0.05$, Ho is accepted, and $\mathrm{Ha}$ is rejected. While on the charge of Natural Sciences F count 0.334 level of significance or probability 0.565 , then $\mathrm{Ho}$ is accepted and $\mathrm{Ha}$ is rejected. Related to the effective Problem Based Learning model in the Make A Match model in terms of Thematic critical thinking in fifth grade students of SD Negeri Sidorejo Lor 04 and SD Negeri Sidorejo Lor 05.

\footnotetext{
1 Corresponding author.

E-mail addresses: asuan656@Gmail.com (Asuan)
} 


\section{Pendahuluan}

Pendidikan adalah hal yang penting dan perlu diperhatikan terutama bagi generasi penerus bangsa sekarang ini. Dari masa ke masa, pendidikan yang ada di Indonesia terus berkembang. Wujud perkembangan pendidikan yang ada di Indonesia salah satunya yaitu dengan penerapan kurikulum yang dari waktu ke waktu terus diperbaiki agar seiring perkembangan zaman dapat meningkatkan kualitas dan mutu pendidikan sekarang ini. Proses pendidikan dipengaruhi oleh banyak faktor antara lain: input peserta didik, sarana dan prasarana pendidikan, bahan ajar, administrasi, sumber daya manusia (pendidiknya) yang mampu mendukung terciptanya suasana yang kondusif. Proses pendidikan yang memperhatikan komponen pendidikan diharapkan dapat menghasilkan peserta didik yang berkualitas. Pendidikan berperan penting dalam menghasilkan generasi-generasi yang berkualitas. Jadi, menurut Anugraheni (2017:247) pendidik mempunyai tugas dalam meningkatkan kualitas, kreativitas, dan mengembangkan potensi yang ada pada peserta didik.

Pendidikan merupakan sebuah sistem. Sebagai sistem, aktivitas pendidikan terbangun dalam beberapa komponen, yaitu pendidik, peserta didik, tujuan pendidikan, alat pendidikan, dan lingkungan pendidikan. Semua komponen yang membangun sistem pendidikan, saling berhubungan, saling tergantung, dan saling menentukan satu sama lain. Setiap komponen memiliki fungsi masing-masing dalam rangka mencapai tujuan pendidikan. Aktivitas pendidikan akan terselenggara dengan baik apabila didukung oleh komponen-komponen dimaksud. Fungsi pendidikan sebenarnya adalah menyediakan fasilitas yang dapat memungkinkan tugas pendidikan dapat berjalan lancar, baik secara struktural, maupun secara institusional. Secara struktural menuntut terwujudnya struktur organisasi yang mengatur jalannya proses kependidikan. Secara institusional mengandung implikasi bahwa proses kependidikan yang terjadi dalam struktur organisasi itu dilembagakan untuk lebih menjamin proses pendidikan itu berjalan secara konsisten dan berkesinambungan mengikuti kebutuhan dan perkembangan manusia yang cenderung ke arah tingkat kemampuan yang optimal (Saat, 2015).

Pasal 1 UU SISDIKNAS no. 20 tahun 2003 disebutkan bahwa Sistem Pendidikan Nasional adalah keseluruhan komponen pendidikan yang saling terkait secara terpadu untuk mencapai tujuan pendidikan nasional. Berangkat dari bunyi pasal ini dapat diketahui bahwa pendidikan adalah sistem yang merupakan suatu totalitas struktur yang terdiri dari komponen yang saling terkait dan secara bersama menuju kepada tercapainya tujuan (Soetarno, 2003: 2). Adapun komponen-komponen dalam pendidikan nasional antara lain adalah lingkungan, sarana-prasarana, sumberdaya, dan masyarakat. Komponen-komponen tersebut bekerja secara bersama-sama, saling terkait dan mendukung dalam mencapai tujuan pendidikan. Tujuan pendidikan nasional yang dirumuskan dalam UU SISDIKNAS adalah untuk mengembangkan potensi anak didik agar menjadi manusia yang beriman dan bertakwa kepada Tuhan Yang Maha Esa, berakhlak mulia, sehat, berilmu, cakap, kreatif, mandiri, dan menjadi warga Negara yang demokratis serta bertanggung jawab (Munirah, 2015).

Pembelajaran tematik adalah suatu pembelajaran yang memadukan beberapa pokok bahasan dalam tema.Tema yang ditentukan sebaiknya tidak terlalu luas, agar dapat digunakan untuk memadukan beberapa mata pelajaran, mewadahi minat peserta didik sehingga hasil belajar dapat dicapai secara optimal serta memepertimbangkan peristiwa autentik yang terjadi saat pembelajaran (Dewi, Kristiantari, Negara, 2014: 3).

Keberhasilan para peserta didik dalam mempelajari pembelajaran tematik bisa dipengaruhi oleh beberapa faktor, diantaranya seperti peran guru saat melakukan pembelajaran pengaruhnya akan sangat besar dalam keberhasilan peserta didik. Sebagai seorang pendidik tidak hanya dituntut untuk memiliki pengetahuan dan keterampilan saat melakukan kegiatan belajar mengajar dikelas, tetapi juga harus memiliki kreativitas. Diantaranya dalam pemilihan model pembelajaran yang sesuai. (Desty Lusia Sari dan Mawardi, 2015:82-99).

Salah satu indikator guru profesional adalah guru yang mampu beradaptasi dengan perkembangan keilmuan yang hari demi hari semakin canggih. Selain itu, guru yang profesional dan kompeten juga harus mampu menerapkan model dan metode pembelajaran berdasarkan tuntutan waktu dan kebutuhan peserta didik. Penerapan pola ini akan menciptakan suasana menyenangkan dalam belajar, enjoy dalam mengajar, yang pada akhirnya akan menghasilkan proses KBM yang berkualitas termasuk peserta didik yang berprestasi (Desilawati, 2014).

Model pembelajaran adalah suatu kerangka konseptual untuk merancang dan melaksanakan suatu pembelajaran, mengorganisasikan pengalaman belajar untuk mencapai tujuan atau kompetensi, dan sebagai pedoman dalam proses pembelajaran karena berisi langkah-langkah pembelajaran yang sistematis. Model pembelajaran umumnya berkaitan erat dengan media pembelajaran. Media pembelajaran merupakan segala sesuatu yang dapat digunakan sebagai sarana untuk menyalurkan pesan dan informasi materi pembelajaran sehingga terjadi proses belajar (Mawardi, 2018: 29). 
Kurikulum 2013 sudah mulai diterapkan pada pendidikan di Indonesia saat ini. Kurikulum 2013 dirancang agar dapat menjawab kebutuhan zaman sekarang ini. Dalam pembelajaran integratif, keterlibatan siswa dalam proses pembelajaran lebih diutamakan dan mata pelajaran yang satu dengan lainnya saling berkaitan (Mawardi, 2014:109).

Dalam proses pembelajaran tematik, salah satu keterampilan yang perlu dikembangkan untuk mencapai keterampilan abad 21 adalah keterampilan berpikir kritis dalam menyelesaikan atau memecahkan masalah. Keterampilan berpikir kritis perlu dikembangkan kepada setiap siswa. Berpikir kritis sangat penting bagi siswa, dengan berpikir kritis siswa dapat memecahkan segala permasalahan yang ada di dalam dunia nyata. Menurut Christina dan Kristin ( 2016:222) berpikir kritis merupakan kemampuan seseorang dalam menemukan informasi dan pemecahan dari suatu masalah dengan cara bertanya kepada dirinya sendiri untuk menggali informasi tentang masalah yang sedang dihadapi. Keterampilan berpikir kritis merupakan hal yang penting bagi siswa, namun pada mata pelajaran tematik terutama dalam menyelesaikan soal, pembelajaran pun cenderung berpusat pada guru. Kemampuan berpikir kritis setiap individu berbeda-beda, tergantung pada latihan yang sering dilakukan untuk mengembangkan berpikir kritis (Fakhriyah, F., 2014:96).

Dalam proses pembelajaran Kurikulum 2013 dilaksanakan dengan menggunakan pendekatan ilmiah. Salah satunya dengan cara menerapkan model pembelajaran yang bisa menempatkan siswa sebagai pusat pembelajaran yaitu dengan menerapkan model Problem Based Learning dan Make A Match. Model Problem Based Learning adalah pembelajaran yang berdasarkan pada masalah-masalah yang dihadapi siswa terkait dengan KD yang sedang dipelajari siswa.Sedangkan model Make A Match merupakan model pembelajaran yang dilakukan dengan menjodohkan kartu soal dan kartu jawaban sesuai kartu yang dipegang masing-masing peserta didik. Melalui pembelajaran ini, memberikan kesempatan peserta didik untuk mengkatkan pemahaman mengenai materi sehingga peserta didik dapat menentukan pasangan yang tepat dan dapat mengkomunikasikan didepan kelas dengan pasangan (Sari \& Mawardi, 2015: 87).

Model pembelajaran Problem Based Learningdan Make A Matchdapat menjadi solusi untuk mengatasi rendahnya kemampuan berpikir kritis siswa kelas 5 SD Negeri Sidorejo Lor 04 dan SD Negeri Sidorejo Lor 05 Salatiga dalam menyelesaikan soal pada mata pelajaran Tematik. Penerapan model Problem Based Learning dalam proses pembelajaran dapat membantu siswa dalam memecahkan masalah, belajar sendiri, kerja sama tim, dan memperoleh pengetahuan yang luas.

Permasalahan dalam penelitian ini berkaitan dengan efektivitas model Problem Based Learning dan Make A Match secara signifikan ditinjau dari keterampilan berpikir kritis pada Tematik siswa kelas 5 SD Negeri Sidorejo Lor 04 dan SD Negeri Sidorejo Lor 05.

\section{Metode}

Jenis Penelitian yang digunakan adalah jenis penelitian eksperimen semu (quasi experiment). Penelitian eksperimen bertujuan untuk mengetahui keterampilan berpikir kritis tematik dengan penerapan model pembelajaran Problem Based Learningdan model pembelajaranMake A Match, teknik pengumpulan data pada penelitian ini menggunakan kuesioner, soal pre-test dan post-test dalam bentuk soal. Penelitian dilakukan pada SD SD Negeri Sidorejo Lor 04 pada tanggal 22-23 Juli 2019 dan SD Negeri Sidorejo Lor 05 pada tanggal 24-25 Juli 2019.

Teknik analisis data yang digunakan adalah teknik analisis deskriptif kuantitatif. Metode kuantitatif sebagai metode ilmiah/scientific karena memenuhi kaidah-kaidah ilmiah yaitu konkrit/empiris, obyektif, terukur, rasional, dan sistematis. Data dalam penelitian berupa angka-angka dan analisi menggunakan statistika.

\section{Hasil dan Pembahasan}

Tabel 1. Data Hasil Keterampilan Berpikir Kritis Kekas Eksperimen dan Kontrol dengan Menggunakan Kuesioner

\begin{tabular}{|c|c|c|c|c|c|c|c|c|}
\hline \multirow{2}{*}{$\begin{array}{l}\text { Indikator } \\
\text { Berpikir } \\
\text { Kritis }\end{array}$} & \multicolumn{4}{|c|}{ Eksperimen } & \multicolumn{4}{|c|}{ Kontrol } \\
\hline & Nilai & Kriteria & $\begin{array}{c}\text { Frekuen } \\
\text { si }\end{array}$ & $\begin{array}{l}\text { Persenta } \\
\text { se }\end{array}$ & Nilai & $\begin{array}{c}\text { Kriteri } \\
\mathbf{a}\end{array}$ & $\begin{array}{c}\text { Freku } \\
\text { ensi }\end{array}$ & Persentase \\
\hline $\begin{array}{l}\text { 1. Mampu } \\
\text { Menganalisis } \\
\text { Argumen }\end{array}$ & 73,35 & $\begin{array}{l}\text { Cukup } \\
\text { Kritis }\end{array}$ & 29 & $80,56 \%$ & 62,05 & $\begin{array}{l}\text { Tidak } \\
\text { Kritis }\end{array}$ & 19 & $52,78 \%$ \\
\hline 2.Mampu & 71,25 & Cukup & 27 & $75 \%$ & 60,15 & Tidak & 16 & $44,44 \%$ \\
\hline
\end{tabular}




\begin{tabular}{|c|c|c|c|c|c|c|c|c|}
\hline Bertanya & & Kritis & & & & Kritis & & \\
\hline $\begin{array}{l}\text { 3. Mampu } \\
\text { Menjawab } \\
\text { Pertanyaan }\end{array}$ & 74,15 & $\begin{array}{l}\text { Cukup } \\
\text { Kritis }\end{array}$ & 30 & $83,33 \%$ & 59,6 & $\begin{array}{l}\text { Tidak } \\
\text { Kritis }\end{array}$ & 15 & $41,67 \%$ \\
\hline $\begin{array}{l}\text { 4. Mampu } \\
\text { Memecahkan } \\
\text { Masalah }\end{array}$ & 78,13 & $\begin{array}{l}\text { Cukup } \\
\text { Kritis }\end{array}$ & 29 & $80,56 \%$ & 61,06 & $\begin{array}{l}\text { Tidak } \\
\text { Kritis }\end{array}$ & 17 & $47,22 \%$ \\
\hline $\begin{array}{l}\text { 5. Mampu } \\
\text { Membuat } \\
\text { Kesimpulan }\end{array}$ & 74,2 & $\begin{array}{l}\text { Cukup } \\
\text { Kritis }\end{array}$ & 29 & $80,56 \%$ & 60,2 & $\begin{array}{l}\text { Tidak } \\
\text { Kritis }\end{array}$ & 15 & $41,67 \%$ \\
\hline $\begin{array}{l}\text { 6. Mampu } \\
\text { Mengevaluas } \\
\text { i atau Menilai }\end{array}$ & 76,67 & $\begin{array}{l}\text { Cukup } \\
\text { Kritis }\end{array}$ & 30 & $83,33 \%$ & 62 & $\begin{array}{l}\text { Tidak } \\
\text { Kritis }\end{array}$ & 16 & $44,44 \%$ \\
\hline $\begin{array}{l}\text { 7. Keseluruhan } \\
\text { Indikator }\end{array}$ & 74,21 & $\begin{array}{l}\text { Cukup } \\
\text { Kritis }\end{array}$ & 30 & $83,33 \%$ & 60,82 & $\begin{array}{l}\text { Tidak } \\
\text { Kritis }\end{array}$ & 12 & $33,33 \%$ \\
\hline
\end{tabular}

Dari Tabel 1, keterampilan berpikir kritis siswa kondisi awal pada indikator 1 hingga indikator 6 masuk ke dalam kriteria tidak kritis. Persentase jumlah siswa yang minimal cukup kritis pada indikator 2 hingga indikator 6 berada di bawah 50\%. Dari hasil kuesioner kelas eksperimen, terlihat bahwa keterampilan berpikir kritis siswa pada indikator 1 hingga indikator 6 masuk dalam kriteria cukup kritis. Persentase jumlah siswa yang minimal cukup kritis pada indikator 1 hingga indikator 6 berada di atas $50 \%$. Hasil dari keterampilan berpikir kritis tersebut sejalan dengan pengertian berpikir kritis yaitu keterampilan seseorang dalam menemukan informasi dan pemecahan dari suatu masalah dengan cara bertanya kepada dirinya sendiri untuk menggali informasi tentang masalah yang sedang dihadapi (Christina, L. V., \& Kristin, F., 2016:222).

Tabel 2. Data Hasil Pengamatan Keterampilan Berpikir Kritis Kelas Eksperimen dan Kelas Kontrol

\begin{tabular}{|c|c|c|c|c|c|c|c|c|c|c|c|c|c|}
\hline \multirow{3}{*}{$\begin{array}{l}\text { Indika } \\
\text { tor }\end{array}$} & \multicolumn{6}{|c|}{ Kontrol } & \multicolumn{6}{|c|}{ Eksperimen } & \multirow{3}{*}{$\begin{array}{l}\text { Peningkatan } \\
\text { Jumlah Skor }\end{array}$} \\
\hline & \multicolumn{4}{|c|}{$\begin{array}{c}\text { Frekuensi } \\
\text { Alternatif } \\
\text { Jawaban }\end{array}$} & \multirow[t]{2}{*}{$\begin{array}{l}\text { Jumlah } \\
\text { Skor }\end{array}$} & \multirow[t]{2}{*}{ Kriteria } & \multicolumn{4}{|c|}{$\begin{array}{c}\text { Frekuensi } \\
\text { Alternatif Jawaban }\end{array}$} & \multirow[t]{2}{*}{$\begin{array}{l}\text { Jumla } \\
\text { h Skor }\end{array}$} & \multirow[t]{2}{*}{ Kriteria } & \\
\hline & 4 & 3 & 2 & 1 & & & 4 & 3 & 2 & 1 & & & \\
\hline 1 & 2 & $\begin{array}{l}1 \\
8\end{array}$ & $\begin{array}{l}1 \\
2\end{array}$ & 4 & 90 & $\begin{array}{l}\text { Tidak } \\
\text { Kritis }\end{array}$ & 10 & 19 & 7 & 0 & 111 & $\begin{array}{c}\text { Cukup } \\
\text { Kritis }\end{array}$ & 21 \\
\hline 2 & 5 & $\begin{array}{l}1 \\
8\end{array}$ & $\begin{array}{l}1 \\
3\end{array}$ & 0 & 100 & $\begin{array}{c}\text { Cukup } \\
\text { Kritis }\end{array}$ & 17 & 13 & 6 & 0 & 119 & Kritis & 19 \\
\hline 3 & 4 & $\begin{array}{l}1 \\
6\end{array}$ & $\begin{array}{l}1 \\
2\end{array}$ & 4 & 92 & $\begin{array}{l}\text { Tidak } \\
\text { Kritis }\end{array}$ & 11 & 17 & 8 & 0 & 111 & $\begin{array}{c}\text { Cukup } \\
\text { Kritis }\end{array}$ & 19 \\
\hline 4 & 4 & $\begin{array}{l}1 \\
6\end{array}$ & $\begin{array}{l}1 \\
0\end{array}$ & 6 & 90 & $\begin{array}{l}\text { Tidak } \\
\text { Kritis }\end{array}$ & 12 & 18 & 5 & 1 & 113 & $\begin{array}{c}\text { Cukup } \\
\text { Kritis }\end{array}$ & 23 \\
\hline 5 & 4 & $\begin{array}{l}2 \\
1\end{array}$ & $\begin{array}{l}1 \\
1\end{array}$ & 0 & 101 & $\begin{array}{c}\text { Cukup } \\
\text { Kritis }\end{array}$ & 16 & 17 & 3 & 0 & 121 & Kritis & 20 \\
\hline 6 & 3 & $\begin{array}{l}2 \\
0\end{array}$ & $\begin{array}{l}1 \\
2\end{array}$ & 1 & 97 & $\begin{array}{l}\text { Cukup } \\
\text { Kritis }\end{array}$ & 16 & 14 & 6 & 0 & 118 & Kritis & 21 \\
\hline Keseluı & ruhan & an ir & dikato & & 95 & $\begin{array}{l}\text { Cukup } \\
\text { Kritis }\end{array}$ & & & & & 115,5 & Kritis & 20,5 \\
\hline & & & $\begin{array}{l}\text { Rata-1 } \\
\text { senta }\end{array}$ & $\begin{array}{l}\text { rat } \\
\text { ase }\end{array}$ & $\begin{array}{l}2,6 \\
3,89 \%\end{array}$ & & & & & & $\begin{array}{l}\text { Rata-rata } \\
\text { rsentase } 8\end{array}$ & $\begin{array}{l}3,2 \\
3,33 \%\end{array}$ & \\
\hline
\end{tabular}

Berdasarkan Tabel 2, keterampilan berpikir kritis siswa kelas kontrol secara keseluruhan jika dilihat dari hasil pengamatan, didapatkan nilai rata-rata sebesar 2,6 (cukup kritis). Persentase jumlah siswa yang kritis secara keseluruhan pada kelas kontrol yaitu 63,89\% atau sebanyak 23 siswa yang termasuk ke dalam kriteria minimal cukup kritis. Keterampilan berpikir kritis siswa kelas eksperimen secara keseluruhan jika dilihat dari hasil pengamatan, didapatkan rata-rata sebesar 3,2 (kritis). Persentase jumlah siswa yang kritis secara keseluruhan pada kelas eksperimen yaitu $83,33 \%$ atau sebanyak 30 siswa yang termasuk ke dalam kriteria minimal cukup kritis. Pengamatan atau observasi yang dilakukan untuk memperkuat hasil kuesioner keterampilan berpikir kritis siswa ini sejalan dengan 
pengertian observasi bahwa observasi memerlukan pengamatan yang cermat dan pemikiran yang dilakukan secara teratur dan logis. Maka dari itu, arti observasi sama halnya dengan mengamati, bukan hanya sekedar melihat (Atika, T. A., \& Tarigan, U., 2014:22). Gambar 1 adalah grafik yang menunjukkan perbandingan persentase keterampilan berpikir kritis siswa pada kondisi awal dan kondisi akhir yang diukur melalui kuesioner.

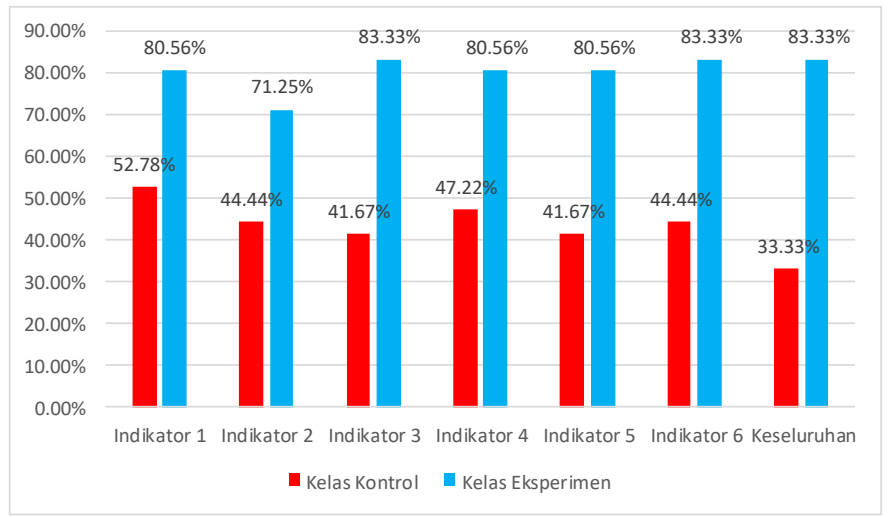

Gambar 1. Persentase Jumlah Siswa yang Kritis

Kelas kontrol pada indikator pertama didapatkan persentase sebesar 52,78\% dan kelas eksperimen didapatkan persentase $80,56 \%$. Selanjutnya kelas kontrol pada indikator kedua didapatkan persentase sebesar $44,44 \%$ dan kkelas eksperimen didapatkan persentase $71,25 \%$. Kelas kontrol pada indikator ketiga didapatkan persentase sebesar $41,67 \%$ dan kelas eksperimen didapatkan persentase sebesar $83,33 \%$. Kelas kontrol pada indikator keempat didapatkan persentase sebesar 47,22\% dan kelas eksperimen didapatkan persentase sebesar $80,56 \%$. Kelas kontrol pada indikator kelima didapatkan persentase sebesar $41,67 \%$ dan kelas eksperimen didapatkan persentase sebesar 80,56\%. Kelas kontrol pada indikator keenam didapatkan persentase sebesar $44,44 \%$ dan kelas eksperimen didapatkan persentase sebesar $83,33 \%$. Kelas kontrol pada indikator secara keseluruhan didapatkan persentase sebesar 33,33\% dan indikator kelas eksperimen didapatkan persentase sebesar 83,33\%. Hasil pengamatan yang dilakukan untuk memperkuat hasil kuesioner keterampilan berpikir kritis disajikan pada gambar 2 di bawah ini

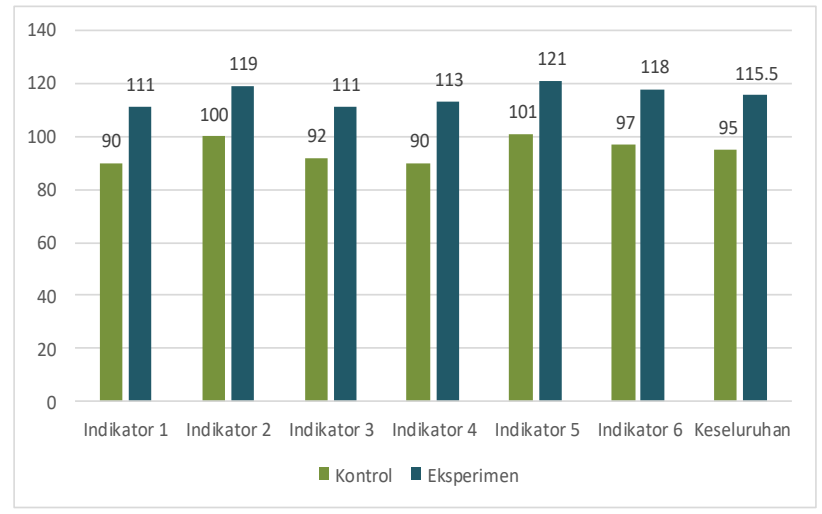

Gambar 2. Observasi Keterampilan Berpikir Kritis Siswa

Kelas kontrol pada indikator pertama didapatkan skor 90 sedangkan kelas eksperimen didapatkan skor 111. Kelas kontrol pada indikator kedua didapatkan skor 100 sedangkan kelas eksperimen didapatkan skor 119. Kelas kontrol pada indikator ketiga didapatkan skor 92 sedangkan kelas eksperimen didapatkan skor 111. Kelas kontrol pada indikator keempat didapatkan skor 90 sedangkan kelas eksperimen didapatkan skor 113. Kelas kontrol pada indikator kelima didapatkan skor 101 sedangkan kelas eksperimen didapatkan skor 121. Kelas kontrol pada indikator keenam didapatkan skor 97 sedangkan kelas eksperimen didapatkan skor 118. Indikator keseluruhan kelas kontrol didapatkan skor 95 sedangkan kelas eksperimen didapatkan skor 115,5.

Dalam penelitian ini, proses pembelajaran pada eksperimen 1 dan eksperimen 2 sudah berjalan sesuai dengan langkah-langkah model pembelajaran Problem Based Learning dan Make a Match. Langkah- 
langkah model pembelajaran Problem Based Learning yang digunakan yaitu orientasi siswa pada masalah, mengorganisasi siswa untuk belajar, membimbing pengalaman individual atau kelompok, mengembangkan dan menyajikan hasil karya, dan menganalisis dan mengevaluasi proses pemecahan masalah (Rusman, 2017:347).

Hasil penelitian ini sejalan dengan pengertian berpikir kritis yaitu kemampuan seseorang dalam menemukan informasi dan pemecahan dari suatu masalah untuk menggali informasi tentang masalah yang sedang dihadapi dengan cara bertanya kepada dirinya sendiri (Christina, L. V., \& Kristin, F., 2016:222), dimana setelah penelitian ini dilakukan, siswa mampu untuk menemukan informasi dan melakukan pemecahan suatu masalah.

Peneliti melakukan Uji normalitas untuk mengetahui data berasal dari distribusi normal atau tidak. Uji normalitas data dilakukan dengan bantuan uji Kolmogrov Smirnov, Slameto (2015: 295) jika nilai siginifikansi/probabitas $<0,05$, maka data distribusi tidak normal. Apabila nilai signifikansi/probabitas $>$ 0,05, maka data berdistribusi normal. Dari uji normalitas diketahui bahwa nilai uji Kolmogorov Smirnov Z hasil pretest-posttest pada muata Bahasa Indonesia kelompok eksperimen 1 adalah 0,134 dan 0,200. Sedangkan hasil pretest-posttest kelompok eksperimen 2 adalah 0,110 dan 0,131. Jika dirumuskan hipotesis Ho adalah sebuah sampel yang berasal dari populasi berdistribusi normal dan Ha adalah sampel yang tidak berasal dari populasi berdistribusi normal, maka dapat diputuskan jika probabitas $<$ nilai $\alpha$ $(0,05)$ Ho ditolak. Jika sebaliknya maka Ho diterima. Karena nilai signifikansi/probabitas data pada muatan Bahasa Indonesia tersebut adalah 0,134, 0,200; 0,110, dan 0,131 > 0,05 maka Ho diterima. Jadi dapat disimpulakan bahwa persebaran data pada muatan Bahasa Indonesia hasil pretest-posttest kelompok eksperimen 1 dan kelompok eksperimen 2 tersebut berasal dari populasi yang berdistribusi normal. Setelah itu dilakukan uji homogenitas untuk mengetahui varian kedua kelompok tersebut homogen atau tidak. Slameto (2015: 298) apabila nilai signifikansi/probabitas < 0,05, maka dikatakan tidak homogen. Sebaliknya jika nilai signifikansi/probabitas $>0,05$, maka data dikatakan homogen. Dari hasil Test of Homogeneity of Variances signifikan/probabilitas nilai pretest menunjukkan 0,196. Dirumuskan sebuah hipotesis H0 adalah variasi data pada tiap kelompok sama (homogen) da Ha adalah variansi data pada setiap kelompok tida sama (tidak homogen), maka dapat diputuskan jika probabilitas < nilai $\alpha(0,05) \mathrm{HO}$ ditolak, jika sebaliknya maka Ho diterima. Oleh karena itu nilai signifikansi/probabilitas data pretest dan posttest pada muatan Bahasa Indonesia kedua kelompok adalah sebesar 0,258 dan 0,775 $>0,05$ maka Ho diterima. Artinya dapat dikatakan bahwa skor pretes tematik dengan dua muatan Bahasa Indonesia dan Ilmu Pengetahuan Alam kelompok eksperimen 1 dan kelompok eksperimen 2 adalah homogen.Skor signifikansi/probabilitas posttesttematik dengan dua muatan Ilmu Pengethuan Alam dan Bahasa Indonesia kelompok eksperimen 1 dan kelompok eksperimen 2 adalah juga homogen. Melihat skor signifikansi/probabilitas pretest-posttest kelompok eksperimen 1 dan kelompok eksperimen 2, dapat disimpulkan bahwa data skor pretest-posttest kelompok eksperimen 1 dan kelompok eksperimen 2 memiliki variasi data yang semuanya homogen. Setelah dilakukan uji normalitas dan homogenitas kemudian dilanjutkan denganuji homogenitas koefisien regresi linier untuk mengetahui kehomogenitasan koefisien regresi X2 (variabel kovariat-pretest) dengan (Y) hasil belajar. Jika probabilitas lebih kecil dari 0,05 maka koefisien regresi linier kedua sampel homogen. Dapat dilihat nilai beta (B) pada muatan Bahasa Indonesia sebesar 0,608 lebih besar dari 0,60, nilai t sebesar 4,759 berada pada signifikansi/probabilitas 0,000, maka koefisien regresi linier kedua sampel homogen dan model ANCOVA dapat digunakan.

Berdasarkan hasil uji normalitas yang menunjukkan data berdistribusi normal, uji homogenitas yang menunjukkan varian data homogen, dan uji homogenitas regresi linier maka dapat dikatakan uji prasyarat sudah terpenuhi. Uji analisis berikutnya adalah ANCOVA atau uji kombinasi analisis regresi dan varians.

Tabel 3. Hasil Uji Ancova Muatan Bahasa Indonesia Tests of Between-Subjects Effects

\begin{tabular}{|c|c|c|c|c|c|c|}
\hline Source & $\begin{array}{c}\text { Type III } \\
\text { Sum of } \\
\text { Squares }\end{array}$ & Df & Mean Squa & $\mathrm{F}$ & Sig. & $\begin{array}{c}\text { Partial Eta } \\
\text { Squared }\end{array}$ \\
\hline $\begin{array}{l}\text { Corrected } \\
\text { Model }\end{array}$ & $2967.017^{\mathrm{a}}$ & 2 & 1483.509 & 15.082 & .000 & .301 \\
\hline Intercept & 10910.273 & 1 & 10910.273 & 110.917 & .000 & .301 \\
\hline Pretest & 2228.170 & 1 & 2228.170 & 22.652 & .000 & .613 \\
\hline Model & 154.464 & 1 & 154.464 & 1.570 & .214 & .244 \\
\hline Error & 6885.476 & 70 & 98.364 & & & .022 \\
\hline Total & 467977.000 & 73 & & & & \\
\hline Corrected & 9852.493 & 72 & & & & \\
\hline
\end{tabular}


Total

Sumber : Data diolah (2019) pada SPSS 22

Berdasarkan Tabel 3 pada muatan Ilmu Pengetahuan Alam kelompok eksperimen adalah 0,139 dan 0,168. Sedangkan hasil pretest-posttest kelompok eksperimen kontrol 0,126 dan 0,141. Jika dirumuskan hipotesis Ho adalah sebuah sampel yang berasal dari populasi berdistribusi normal dan Ha adalah sampel yang tidak berasal dari populasi berdistribusi normal, maka dapat diputuskan jika probabitas < nilai $\alpha(0,05)$ Ho ditolak, jika sebaliknya maka Ho diterima. Karena nilai signifikansi/probabitas data pada 0,139, 0168, 0,126, dan 0,141 >0,05 maka Ho diterima. Jadi dapat disimpulkan bahwa persebaran data pada muatan Bahasa Indonesia hasil pretest-posttest kelompok eksperimen 1 dan kelompok eksperimen 2 tersebut berasal dari populasi yang berdistribusi normal. Setelah itu dilakukan uji homogenitas untuk mengetahui varian kedua kelompok tersebut homogen atau tidak. Slameto (2015:298) apabila nilai signifikansi/probabitas < 0,05, maka dikatakan tidak homogen. Sebaliknya jika nilai signifikansi/probabitas $>0,05$, maka data dikatakan homogen. Dari hasil Test of Homogeneity of Variances signifikan/probabilitas nilai pretest menunjukkan 0,196. Dirumuskan sebuah hipotesis Ho adalah variasi data pada tiap kelompok sama (homogen) da Ha adalah variansi data pada setiap kelompok tida sama (tidak homogen), maka dapat diputuskan jika probabilitas $<$ nilai $\alpha(0,05)$ Ho ditolak, jika sebaliknya maka Ho diterima. Oleh karena itu nilai signifikansi/probabilitas data pretest dan posttest pada muatan Bahasa Indonesia adalah 0,535 dan 0,709>0,05 maka Ho diterima. Setelah dilakukan uji normalitas dan homogenitas kemudian dilanjutkan denganuji homogenitas koefisien regresi linier untuk mengetahui kehomogenitasan koefisien regresi X2 (variabel kovariat-pretest) dengan (Y) hasil belajar. Jika probabilitas lebih kecil dari 0,05 maka koefisien regresi linier kedua sampel homogen. Dapat dilihat nilai beta (B) pada muatanpada muatan Bahasa Indonesia sebesar 0,604 lebih besar dari 0,60 , nilai t sebesar 3,411 berada pada signifikansi/probabilitas 0,000, maka koefisien regresi linier kedua sampel homogen dan model ANCOVA dapat digunakan.

Tabel 4. Hasil Uji Ancova Muatan Ilmu Pengetahuan AlamTests of Between-Subjects Effects

\begin{tabular}{|c|c|c|c|c|c|c|}
\hline Source & $\begin{array}{l}\text { Type III } \\
\text { Sum of } \\
\text { Squares }\end{array}$ & Df & Mean Squar & $\mathrm{F}$ & Sig. & $\begin{array}{l}\text { Partial Eta } \\
\text { Squared }\end{array}$ \\
\hline $\begin{array}{l}\text { Corrected } \\
\text { Model }\end{array}$ & $1353.202^{\mathrm{a}}$ & 2 & 676.601 & 5.818 & .005 & .143 \\
\hline Intercept & 13187.957 & 1 & 13187.957 & 113.394 & .000 & .618 \\
\hline Pretest & 1352.846 & 1 & 1352.846 & 11.632 & .001 & .142 \\
\hline Model & 38.889 & 1 & 38.889 & .334 & .565 & .005 \\
\hline Error & 8141.127 & 70 & 116.302 & & & \\
\hline Total & 432207.000 & 73 & & & & \\
\hline $\begin{array}{l}\text { Corrected } \\
\text { Total }\end{array}$ & 9494.329 & 72 & & & & \\
\hline
\end{tabular}

Peningkatan keterampilan berpikir kritis diperoleh dari hasil kuesioner yang diisi oleh siswa pada kondisi awal dan kondisi akhir serta diperkuat dengan pengamatan langsung oleh peneliti. Pada indikator pertama terjadi peningkatan dari 62,05 (tidak kritis) menjadi 72,35 (cukup kritis). Indikator kedua terjadi peningkatan dari 60,15 (tidak kritis) menjadi 71,25 (cukup kritis). Selanjutnya pada indikator ketiga juga mengalami peningkatan dari 59,6 (tidak kritis) menjadi 74,15 (cukup kritis). Indikator keempat juga terjadi peningkatan dari 61,06 (tidak kritis) menjadi 78,13 (cukup kritis). Pada indikator kelima juga terlihat ada peningkatan dari 60,2 (tidak kritis) menjadi 74,2 (cukup kritis). Indikator keenam juga masih terjadi peningkatan dari 62 (tidak kritis) menjadi 76,67 (cukup kritis). Secara keseluruhan terdapat nilai dari kondisi awal sebesar 60,82 (tidak kritis) meningkat menjadi 74,21 (cukup kritis) dan terjadi peningkatan sebanyak 13,39.

Selain dilihat dari nilai, peningkatan keterampilan berpikir kritis juga dapat dilihat dari persentase jumlah siswa yang kritis. Indikator pertama terjadi peningkatan dari 52,78\% (sangat tidak kritis) menjadi80,56\% (kritis). Indikator kedua terjadi peningkatan dari 44,44\% (sangat tidak kritis) menjadi 75\% (cukup kritis). Indikator ketiga juga terjadi peningkatan dari 41,67\% (sangat tidak kritis) menjadi 83,33\% (kritis). Indikator keempat terjadi peningkatan dari 47,22\% (sangat tidak kritis) menjadi $80,56 \%$ (kritis). Indikator kelima juga masih terjadi peningkatan dari $41,67 \%$ (sangat tidak kritis) menjadi 80,56\% (kritis). Indikator keenam juga terjadi peningkatan dari 44,44\% (sangat tidak kritis) menjadi 83,33\% (kritis). Sedangkan secara keseluruhan peningkatan persentase kondisi awal sebesar 33,33\% 
(sangat tidak kritis) menjadi $83,33 \%$ (kritis) pada kondisi akhir dengan target $70 \%$ atau meningkat sebesar $50 \%$.

Hasil uji hipotesis menggunakan teknik ANCOVA seperti yang telah dilakukan terhadap nilai pretest dan posttest kelompok eksperimen 1 dan kelompok eksperimen 2 diperoleh hasil signifikansi/probabilitas $0,000<0,05$, oleh karena probabilitas lebih kecil dari nilai Alpha, maka Ho diterima dan Ha ditolak. Maknanya tidak ada perbedaan yang signifikan model Problem Based Learning Make A Match ditinjau dari keterampilan berpikir kritis Tematik pada peserta didik kelas 5 SD Negeri Sidorejo Lor 04 dan SD Negeri Sidorejo Lor 05.

Pembelajaran menggunakan model Problem Based Learning dapat meningkatkatkan keterampilan berpikir kritis peserta didik, tetapi tidak kalah ampuh dengan model Make A Match karena selisih ratarata dari kedua model hanyalah sedikit. Model pembelajaran Make A Match juga memiliki sintak pembelajaran yang menarik dan dapat memunculkan kerjasama dan keaktifan peserta didik. Sintak model pembelajaran Make A Match menurut Febriana (2011:155) antara lain: 1) guru menyiapkan kartu yang berisi persoalan-persoalan dan kartu yang berisi jawabannya, 2) setiap peserta didik mencari dan mendapatkan sebuah kartu soal dan berusaha menjawabnya, 3) setiap peserta didik mencari kartu yang cocok dengan persoalannya, 4) peserta didik yang benar mendapat nilai-reward, 5) kartu dikumpulkan dan dikocok, 6) babak berikutnya pembelajaran seperti babak pertama, penyimpulan dan evaluasi, refleksi.

Penelitian yang dilakukan oleh Rosita dan Bahriah (2016) membuktikan bahwa model Problem Based Learning lebih efektif dibandingkan dengan metode ceramah maupun tanya jawab. Keterampilan berpikir kritis menurut Setyorini, Sukiswo, dan Subali (2011) dapat ditingkatkan dengan model pembelajaran PBL. Model PBL mengajak siswa agar mampu agar mampu melatih keterampilan siswa dalam memecahkan masalah sehingga dapat meningkatkan keterampilan berpikir kritis peserta didik. Penelitian lain yang senada dengan hasil penelitian adalah penelitian yang dilakukan oleh Masek (2011) dalam reviewnya menyebutkan bahwa secara teori proses model Problem Based Learning dapat mendukung keterampilan berpikir kritis peserta didik.

\section{Simpulan dan Saran}

Berdasarkan hasil pembahasan analisis data yang telah dibahas pada BAB IV dan setelah dilakukan penelitian di SD Negeri Sidorejo Lor 04 dan SD Negeri Sidorejo Lor 05 maka dapat disimpulkan bahwa

1. Keterampilan berpikir kritis menggunakan model pembelajaran Make A Match tidak lebih efektif secara signifikan dari model Problem Based Learning pada peserta didik kelas 5 SD Negeri Sidorejo Lor 04 dan SD Negeri Sidorejo Lor 05. Hal tersebut dapat dibuktikan setelah dilakukan uji Ancova diperoleh hasil F hitung dalam muatan Bahasa Indonesia 1,570 taraf signifikan atau probabilitas 0,214 $>0,05$, artinya ${ }^{\mathrm{H}_{0}}$ diterima dan ${ }^{\mathrm{H}}{ }_{a}$ ditolak.

2. Keterampilan berpikir kritis menggunakan model Make A Match tidak lebih efektif secara signifikan dari model Problem Based Learning pada peserta didik kelas 5 SD SD Negeri Sidorejo Lor 04 dan SD Negeri Sidorejo Lor 05. Hal tersebut dapat dibuktikan setelah dilakukan uji Ancova diperoleh hasil F hitung dalam muatan Bahasa Indonesia 0,334 taraf signifikan atau probabilitas 0,565 $>0,05$, artinya $\mathrm{H}_{0}$ diterima dan $\mathrm{H}_{a}$ ditolak.

Berdasarkan kesimpulan yang telah dipaparkan, maka terdapat beberapa saran yang ditunjukan kepada:

1. Guru

Hasil penelitian ini menunjukan bahwa keterampilan berpikir kritis siswa dengan menggunakan model Problem Based Learning lebih tinggi dari pada keterampilan berpikir siswa dengan menggunakan model pembelajaran Make A Match pada Tematik, oleh sebab itu guru dapat menggunakan model Problem Based Learning pada pembelajaran Tematik kelas 5 SD.

2. Siswa

Penerapan model Problem Based Learning dalam pembelajaran Tematik, diharapkan dapat mendorong peserta didik untuk selalu aktif dalam mengikuti kegiatan pembelajaran dan meningkatkan keterampilan berpikir kritis peserta didik.

\section{Daftar Rujukan}


Anugraheni, I. (2017). Penggunaan Portofolio dalam Perkuliahan Penilaian Pembelajaran. Jurnal Pendidikan Dasar Perkhasa, 3(1), 246-258.

Christina, L. V., \& Kristin, F. (2016).Efektivitas Model Pembelajaran Tipe Group Investigation (GI) dan Cooperative Integrated Reading And Composition (CIRC) Dalam Meningkatkan Kreativitas Berpikir Kritis dan Hasil Belajar IPS Siswa Kelas 4. Scholaria: Jurnal Pendidikan dan Kebudayaan, 6(3), 217230.

Desilawati, Amrizal. 2014. Guru Profesional Di Era Global. . JURNAL Pengabdian Kepada Masyarakat Vol. 20 Nomor 77 Tahun XX September 2014

Fakhriyah, F. (2014).Penerapan Problem Based Learning dalam Upaya Mengembangkan Kemampuan Berpikir Kritis Mahasiswa. Jurnal Pendidikan IPA Indonesia, 3(1).

Huda, M. 2015. Cooperatif Learning. Yogyakarta: Pustaka Pelajar.

Mawardi, M. (2014).Pemberlakuan Kurikulum SD/MI Tahun 2013 dan Implikasinya terhadap Upaya Memperbaiki Proses Pembelajaran Melalui PTK. Scholaria: Jurnal Pendidikan dan Kebudayaan, 4(3), 107-121

Mawardi.2018. Merancang Model dan Media Pembelajaran. Scholaria, 1 (1): 29.

Munirah. 2015. Sistem Pendidikan Di Indonesia: Antara Keinginan Dan Realita . Jurnal Auladuna, Vol. 2 No. 2 Desember 2015: 233-245 234

Rusman. (2017). Belajar \& Pembelajaran"Berorientasi Standar Proses Pendidikan". Jakarta: Kencana

Slameto. 2008. Proses Belajar Mengajar. Jakarta: Remaja Rosdakarya

Sadia, I. W. (2008). Model pembelajaran yang efektif untuk meningkatkan keterampilan berpikir kritis (suatu persepsi guru). Jurnal pendidikan dan pengajaran Undiksha, 2(2), 19-237.

Saat, Sulaiman. 2015. Faktor-Faktor Determinan Dalam Pendidikan Studi Tentang Makna Dan Kedudukannya Dalam Pendidikan . Jurnal Al-Ta'dib Vol. 8 No. 2, Juli-Desember 2015 